\title{
Client Satisfaction Towards Municipal Solid Waste Management Service in Jimma City, South West Ethiopia
}

\author{
Yohannis Fetene* \\ Ethiopian Environment \& Forest Research Institute, Jimma Research Center, Ethiopia \\ Submission: July 05, 2018; Published: July 18, 2018 \\ *Corresponding author: Yohannis Fetene, Ethiopian Environment \& Forest Research Institute, Jimma Research Center, Jimma, Ethiopia, \\ Tel: +251 92446 8665; Email: feteneyohannis@yahoo.com
}

Abstract

The present study was conducted on solid waste management of Jimma City municipality to find out the client satisfaction of solid waste management services and to find out the factors associated with client satisfaction of solid waste management services. The study was performed with 260 respondents of Jimma City residents. Data were collected using a structured questionnaire. Majority of the respondents 166 (63.85\%) in the study areas were used municipal solid waste management service rendered by Jimma city municipality. Out of these 124(74.7\%) of clients were unsatisfied with the service. The study revealed that client satisfaction to municipal solid waste management service is statistically associated with waste collection frequency $(X 2=19.8630, d f=6, P<0.05)$. The findings also showed that age, educational status, and family size had significant $(\mathrm{p}<0.05)$ positive correlation with the satisfaction of solid waste management services. From this study it is recommended that solid waste collection time should be properly maintained and City municipality showed increase manpower, labor cost, and transport. NGOs or other organization (government and private) should involve in solid waste management service in Jimma city.

Keywords: Client Satisfaction; Solid Waste Management; Waste Collection Frequency; Jimma city

\section{Introduction}

Solid waste is inextricably linked to urbanization and economic development. The volume of waste generated in the world is enormous and reaching $77 \mathrm{~kg} /$ person/day and continuing to rise [1]. With current world population growth, it is approximated that the load of municipal solid waste (MSW) generated by the year 2020 is about nine million tons/year. The estimation on the national recycling rate is about $3-5 \%$ which is very low as compared with the potential $[1,2]$. The actual solid waste generation per capita rates are highly variable, as there are considerable differences in waste generation rates across countries and cities [3]. Municipal solid waste management constitutes one of the most crucial health and environmental problems become a major challenge in many cities in the developing countries because it involves a huge expenditure and receives scant attention [4,5]. Even though these cities are using 20-50 percent of their budget in solid waste management, only 20-80 percent of the waste is collected. The uncollected or illegally dumped wastes constitute a disaster for human health and the environmental degradation [6]. In many developing countries in Africa, the public sector took monopoly of providing solid waste management services in urban cities and this was largely blamed for the mess in solid waste management. The public sector was commonly reported to be constrained due to lack of managerial and technical capacity, cumbersome procurement procedures and inadequate financial resources.
These constraints have resulted in an increased interest in Public private partnerships in urban solid waste management in many developing countries in recent years with the main objective of improving efficiency in waste collection, reducing costs and reforming the weak performance of the public sector [5].

Municipal Solid Waste management services in Jimma city starts with collection by vehicles with a loading capacity of eight cubic meters and 54 metallic containers with a capacity of four cubic meters for waste storage. Next stage is transportation to the existing dumping sites which is not properly engineered and managed, pollutant that are released from the disposal sites eventually causing direct and indirect impact to human's life. There were no private sectors involved in solid waste collection service to help city administration in this activity except few micro scale enterprises involved in small-scale solid waste collection. The collection system in the city is currently based on the application of communal municipality waste containers and door-to-door collection by the micro scale enterprises. Communal waste collection is performed by means of containers placed randomly in overcrowded residential and commercial areas [7].

A study conducted by Getahun revealed from the total solid waste released by the population in the city of Jimma, about $47 \%$ was collected and the rest $53 \%$ is either indiscriminately 
thrown away at various dumping sites on the periphery of urban centers, or at a number of so-called temporary sites, typically empty lots scattered throughout the city. According to the data for 2011 households took the lion share of solid waste generated in the city. From the total solid waste generated in the city, household took $87 \%$, street $0.1 \%$, institutions and commercial centers 13\% [7]. Quality assessment of waste management services is very relevant in view of the health consequences associated with poor quality waste management services. Thus, the general public and customers of waste management firms are more concerned about the quality of services delivered than they are about how services are provided. Since residents pay user charges for services delivered, they expect the services to be reliable and refuse sites to be devoid of waste overflow, flies and rodents. In view of this, customer satisfaction surveys have become the leading criteria for determining the quality of services delivered to customers and a key performance indicator for both public and private organizations $[5,6]$. The focus of this paper therefore is to assess client's satisfaction towards the municipal solid waste management services provided by Jimma city municipality. Since householders are the major generators of solid waste in the Municipality, it is important to investigate their level of satisfaction and perspectives of the services rendered by city municipality

\section{Materials and Methods}

A cross-sectional study was conducted to assess client satisfaction on municipal solid waste management service in Jimma city. Jimma City has thirteen kebele administrations and based on the projection from a 2007 Ethiopian Central Statistical Agency (CSA) population and housing census report, the current population of Jimma City is estimated to be 155,436 of which females and males account $49.7 \%$ and $50.3 \%$ respectively [8]. The numbers of households in the city are about 27,757. Six kebeles were selected purposively, those expected to have

\section{Results and Discussion}

Table 1: Frequency of Socio-Demographic Characteristics of respondents in Jemma City.

\begin{tabular}{|c|c|c|c|}
\hline Variables & Categories & Number & Percentage (\%) \\
\hline \multirow{6}{*}{ Age of Respondents } & $18-24$ & 20 & $12 \%$ \\
\hline & $25-34$ & 35 & $21 \%$ \\
\hline & $35-44$ & 48 & $29 \%$ \\
\hline & $45-54$ & 30 & $18 \%$ \\
\hline & $55-64$ & 20 & $12 \%$ \\
\hline & $>64$ & 13 & $8 \%$ \\
\hline \multirow{2}{*}{ Sex } & Male & 84 & $32.3 \%$ \\
\hline & Female & 176 & $67.7 \%$ \\
\hline \multirow{3}{*}{ Family Size } & $1-3$ & 44 & 16.92 \\
\hline & $4-6$ & 142 & 54.62 \\
\hline & $>7$ & 74 & 28.46 \\
\hline Educational Status & Unable to read and write & 16 & 6.15 \\
\hline
\end{tabular}




\section{International Journal of Environmental Sciences \& Natural Resources}

\begin{tabular}{|l|c|c|c|}
\hline \multirow{4}{*}{} & Able to read and write & 10 & 3.85 \\
\cline { 2 - 4 } & Grade 1-8 & 56 & 21.54 \\
\cline { 2 - 4 } & Grade 9-10 & 90 & 34.62 \\
\cline { 2 - 4 } & Grade 11-12 & 38 & 14.62 \\
\cline { 2 - 4 } & Certificate \& above & 50 & 19.22 \\
\cline { 2 - 4 } & Single & 77 & 29.62 \\
\cline { 2 - 4 } & Married & 157 & 60.38 \\
\cline { 2 - 4 } & Divorced & 15 & 5.77 \\
\cline { 2 - 4 } & Widowed & 11 & 4.23 \\
\cline { 2 - 4 } & Gov't employee & 62 & 23.85 \\
\cline { 2 - 4 } & Merchant & 44 & 16.92 \\
\cline { 2 - 4 } & Daily Labour & 48 & 18.46 \\
\cline { 2 - 4 } & Carpentry & 4 & 1.54 \\
\cline { 2 - 4 } & Housewife & 44 & 16.92 \\
\hline
\end{tabular}

Table 2: Type of container used for solid waste storage at source by households in Jimma city.

\begin{tabular}{|c|c|c|c|}
\hline S. No. & Type of Container & Number & Percent (\%) \\
\hline 1 & Plastic bag (festal) & 6 & 2.75 \\
\hline 2 & Plastic dust bin & 10 & 4.59 \\
\hline 3 & Sack & 202 & 92.66 \\
\hline & Total & 218 & 100 \\
\hline
\end{tabular}

A total of 260 households were included in this particular study and interviewed on socio demographic characteristics solid waste management systems and client satisfaction and collection skip utilization of solid waste management service delivered by Jemma city municipality. Among a study participant $176(67.7 \%)$ were female and the $84(32.3 \%)$ were males. The family size of the study population was dominated by the households with 4 to 6 occupants (Tables 1 \& 2). A total of 218 (83.85\%) of the households had on site solid waste storage container, the most commonly employed type of containers used for solid waste storage was sack which accounts for 202 $(92.66 \%)$ and the rest were plastic bag $6(2.75 \%)$ and plastic dust bin 10 (4.59\%) (Table 3).

Table 3: On-site solid waste storage practice of the households in Jimma City.

\begin{tabular}{|c|c|c|c|}
\hline S.No & Storage Practice & Number & Percent (\%) \\
\hline 1 & Mixed solid waste & 215 & 98.62 \\
\hline 2 & Separate solid waste & 3 & 1.38 \\
\hline & Total & 218 & 100 \\
\hline
\end{tabular}

None of the less, these all mentioned storage container were not appropriate to handle the solid waste generated by households as some of them were prone to the entrance of files and rodents. Consequently, house sweepings, garbage and discarded items were left on the floor of the houses or thrown in the streets or in the premises compound. Garbage should be stored in a fly tight container and disposed of in such a manner that fly breeding is prevented. proper sanitation with principal emphasis on adequate garbage storage, collection and disposal is considered the most effective fly and rodent control measure available. Effective sanitation practices reduce and delay the onset of pest problems [9].

Table 4: Relationships between solid storage practice and occupation of household in Jimma City.

\begin{tabular}{|c|c|c|c|c|}
\hline \multirow{2}{*}{ S.No. } & \multirow{2}{*}{ Occupation } & \multicolumn{3}{|c|}{ Storage Practice } \\
\cline { 2 - 5 } & Merchant & Mixed Waste & Separate & 39 \\
\hline 1 & Government employee & 39 & 1 & 0 \\
\hline 2 & House wife & 37 & 0 & 37 \\
\hline 3 & Carpentry & 5 & 1 & 47 \\
\hline 4 & Students & 46 & 1 & 7 \\
\hline 5 & Daily labor & 7 & 0 & 34 \\
\hline 7 & Car driver & 34 & 3 & 218 \\
\hline
\end{tabular}


$215(98.62 \%)$ of the households practiced mixed solid waste solid system in one container for all types of waste while only $3(1.38 \%)$ of the households used to store separately (Table 4$)$. However, this not a safe practice as most of the wastes could easily be delayed and encourage propagation of files and rats which are the primary carrier and dispersal agents of diseases in many cases. In agreement with previous study done in Jimma city this study has shown no statistical association between the solid waste storage practice of households and their occupation $(\mathrm{X} 2=12.2854, \mathrm{P}<0.05)$ (Table 5) whether, the respondents is Government employee, students or not, the solid waste storage practice was not found to be associated with their occupation. This is may be due to the fact that practice of the people is not influenced by their occupation.

Table 5: Responses of households to the number of days the waste is kept in the container before disposal in Jimma City.

\begin{tabular}{|c|c|c|c|}
\hline S.No & Number of days & Number & Percent (\%) \\
\hline 1 & Less than 3 days & 26 & 11.93 \\
\hline 2 & Between 3 and 6 & 32 & 14.68 \\
\hline 3 & Greater than 6 days & 160 & 73.39 \\
\hline & Total & 218 & 100 \\
\hline
\end{tabular}

The study finding also showed that 160 (73.39\%) of the households were storing their solid waste for more than six days in storage container before its final disposal, whereas 32 $(14.68 \%)$ of the households used to store wastes for 3 to 6 days and the remaining $26(11.93 \%)$ of the households were found to keep their wastes in storage container for less than three days prior to its final disposal (Table 6). As organic putrescible matter constitutes significant percentage of the waste, it should be collected and disposed of within a maximum of three days before it smells and pollutes the environment. Unless and other wise, all these will pose serious health problems since compost able organic wastes ferment very soon, creating conditions favorable for the insect breeding as well as source of offensive odor [10].

Table 6: client satisfaction to municipal solid waste management Service in Jimma city

\begin{tabular}{|c|c|c|c|}
\hline S.No & Client Satisfaction Level & Number & Percent (\%) \\
\hline 1 & Unsatisfactory & 124 & 74.7 \\
\hline 2 & Fair & 34 & 20.48 \\
\hline 3 & Satisfactory & 9 & 5.42 \\
\hline & Total & 166 & 100 \\
\hline
\end{tabular}

Concerning solid waste transportation to the disposal site, daily labors were found to be responsible in $35.78 \%$ of the households to transport the collected solid wastes to disposal site while $27.52 \%$ of responsibility in household waste transport lies in mothers. Fathers were responsible in $11.93 \%$ and the remaining $24.77 \%$ responsible were children's (Figure 1) From the general health point of view, this is an encouraging behavior because the chance of littering in handling the solid wastes. None the less cultural values and beliefs can largely determine what people consider right or appropriate behavior and practice to handle and transport solid waste to disposal sites [11]. A total of $166(63.8 \%)$ of the households were used municipal solid waste management service rendered by Jimma city municipality. Unfortunately, the municipality does not have any education about waste collection.

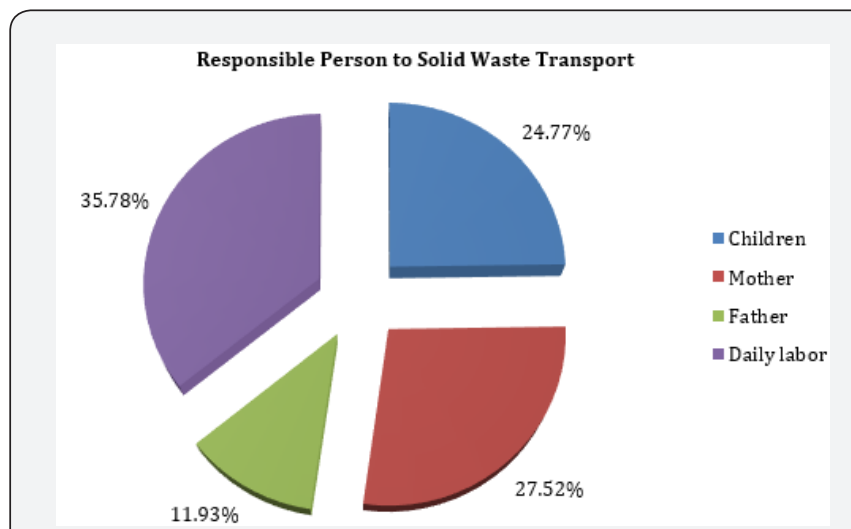

Figure 1: Responsible person to transport solid waste to disposal site in Jimma city.

These may be due to the fact that lack of manpower and municipality may not create relation or cooperation with the communities. But good relation can lead to community participation [7]. Therefore, a program of continuing education is essential in bring about a change in public attitude. The satisfaction level of the respondent household with regard to the waste collection service as provided by the municipality that $124(74.70 \%)$ of the surveyed households are not satisfied with the collection service of the municipality. They think that the municipality has completely failed in proper waste management. $9(20.48 \%)$ of the respondents are satisfied with the services of the municipality (Table 7).

Table 7: Availability and utilization of waste collection skips in Jimma city

\begin{tabular}{|c|rr|c|c|}
\hline S.No & \multicolumn{2}{|c|}{ Waste collection skip } & Number & Percent (\%) \\
\hline 1 & Availability & Yes & 166 & 63.85 \\
\hline 2 & No & 94 & 36.15 \\
\hline & Total & 260 & 100 \\
\hline & & & \\
\hline 1 & Utilization & Yes & 128 & 77.11 \\
\hline 2 & No & 38 & 22.89 \\
\hline & Total & 166 & 100 \\
\hline
\end{tabular}

Of all respondents 124 (74.70\%), who unsatisfied by municipal service; frequency of waste collection from household, reliability of waste collection, prompt response to users complains, handling of waste containers during transportation, cleanliness of service area, household education on solid waste management, availability and accessibility of collection container and overall service delivery were the major reasons that makes them unsatisfied with municipal solid waste management service rendered by Jimma city municipality. 
Regarding the availability and utilization of collection skip, out of 166 respondents, who had availability of waste collection skip only $77.11 \%$ of clients were utilized and $28.89 \%$ of client did not utilized it. Lack of service availability smell and odor problem and discomfort of the skip makes them that they did not utilized the waste collection skip (Table 8).

Table 8: Households' satisfaction level on solid waste collection frequency

\begin{tabular}{|c|c|c|c|}
\hline S.No & $\begin{array}{c}\text { Frequency of Waste } \\
\text { Collection }\end{array}$ & Number & Percent (\%) \\
\hline 1 & Not at all & 42 & 25.30 \\
\hline 2 & Once every two weeks & 40 & 24.10 \\
\hline 3 & Once per week & 20 & 12.05 \\
\hline 4 & Twice per week & 22 & 13.25 \\
\hline 5 & Three per week & 42 & 25.30 \\
\hline & Total & 166 & 100 \\
\hline
\end{tabular}

Collection of solid waste was given scant attention resulting in cities utilizing the cheapest method available with little or no consideration given to that of the server population problems there by created [12]. Unsightly make shift containers and even open ground storage, both of which are undesirable, are often seen at any residential and commercial sites $[13,14]$. The cleanliness of environment of an area depends on the regularity in the collection of waste by the municipality [15]. The response of the household regarding the frequency of waste collection by the municipality is not satisfactory because a major percentage of household answered that the collection of waste is not regular. Out of $124(74.70 \%)$ of client who picked up their wastes at a

time by municipal collection vehicle, only $42(25.30 \%)$ of client were picked their waste three times per week, 22(13.25\%) of clients' waste picked twice per week and $20(12.05 \%)$ of client were picked once per week while the rest $40(24.10 \%)$ of client were pick their wastes once every two weeks (Table 9).

Table 9: Relationships of client satisfaction to municipal solid waste management service and waste collection frequency

\begin{tabular}{|c|c|c|c|c|c|}
\hline S.No & Pick Up Time & \multicolumn{4}{|c|}{ Client Satisfaction } \\
\hline 1 & $\begin{array}{c}\text { Once every 2 } \\
\text { week }\end{array}$ & 13 & 2 & 0 & 15 \\
\hline 2 & $\begin{array}{c}\text { Once per } \\
\text { week }\end{array}$ & 7 & 2 & 1 & 10 \\
\hline 3 & $\begin{array}{c}\text { Twice Per } \\
\text { week }\end{array}$ & 3 & 4 & 1 & 8 \\
\hline 4 & $\begin{array}{c}\text { Three Per } \\
\text { week }\end{array}$ & 0 & 6 & 3 & 9 \\
\hline & Total & 23 & 16 & 5 & 42 \\
\hline
\end{tabular}

Recognizing that our world is finite and that the continued pollution of our environment will be difficult to rectify in the future, solid waste management is both timely and important with the overall objectives to minimize the adverse effects caused by indiscriminate disposal [16]. The study finding has statistical significance between client satisfaction to municipal solid waste management service and waste collection pick up time $(\mathrm{X} 2=$ $19.8630, \mathrm{p}<0.05$ ). This might be due to the fact client satisfaction is influenced by municipal waste collection frequency. The study also revealed that client satisfaction to municipal solid waste management service is statistically associated with waste collection frequency $(\mathrm{X} 2=19.8630, \mathrm{df}=6, \mathrm{P}<0.05)$.

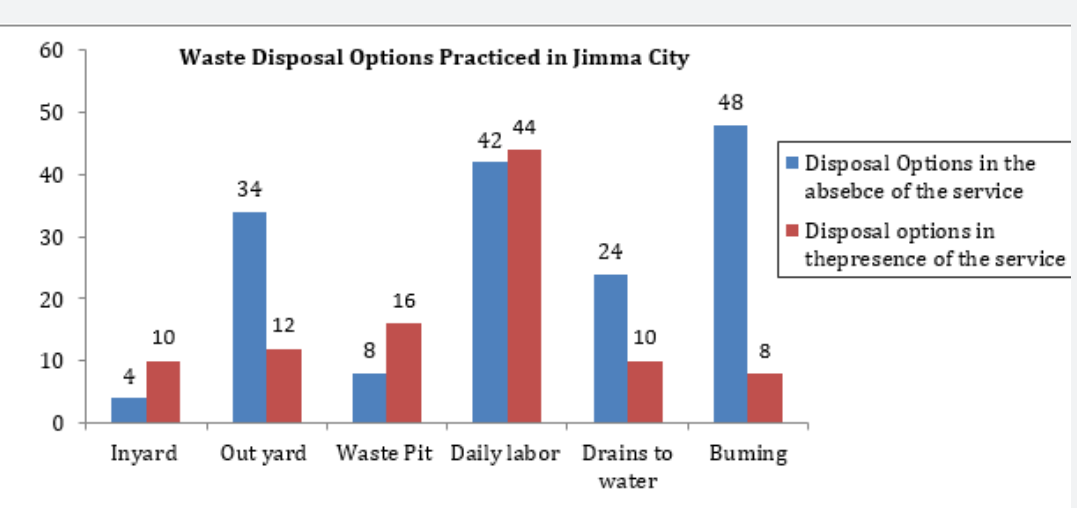

Figure 2: Solid waste disposal options practiced by client in the absence and presence of municipal service in Jimma city.

Regarding solid waste disposal options practiced by client in the absence of municipal service, the study reveals the poor environmental quality and pollution hazard of the area. It is evident that a negligible percentage of the household respondent that they do not observe people throwing waste in the drain while some share of the household 24 (14.6\%) responded that they notice people throwing waste in drains and roadside (data not shown). These improperly dumped wastes are breeding grounds of insects, pests and infectious diseases and also produce toxic gases, which spread odor around the dumping places. The study indicates that a majority of people do not have access to proper waste disposal facilities. Majority of study households dispose their solid waste in uncontrolled methods like inside the yard (6.93\%), outside the yard (4.60\%), waste pit (10.0\%), and give to labor (16.93\%) and into drainage ditches (Figure 2). Although the above mentioned methods are most commonly recognized methods that most people in developing countries like Ethiopia, use for disposal of solid wastes, there are such problem associated with them; such as air pollution, land pollution, waking in the city from any corner all public spaces like road 
sides and open spaces attest eye catching piles of garbage, flying objects, rubbish etc littering the city space indefinitely [14]. The relationship between health and importance of the more obvious ways in which aesthetic standards are abused in the dropping of litters in cities/ improper management of solid waste could well be major factor contributing to litter problems, which regarded as a measure of citizens pride in his/her surroundings $[17,18]$.

\section{Conclusion}

In general, the study revealed that there is little solid waste management system as well as organized service in handling, storage, collection and disposal of solid waste in Jimma city. The satisfaction level of the respondent household with regard to solid waste management service as provided by the municipality that $74.70 \%$ of the surveyed households are not satisfied with the service rendered by the municipality. And they think that the municipality has completely failed in proper waste management in the city. Therefore, it is recommended that solid waste collection time should be properly maintained, and City municipality showed increase manpower, labor cost, and transport. NGOs or other organization (government and private) should involve in solid waste management service in Jimma city.

\section{Acknowledgement}

The authors would like to thank residence of Jimma city, data collectors and City Municipality for their cooperation during data survey.

\section{References}

1. N Khairuddin, L Abd Manaf, M Ali Hassan, N Halimoon, WA Wan Ab Karim (2015) Biogas Harvesting from Organic Fraction of Municipal Solid Waste as a Renewable Energy Resource in Malaysia: A Review. Pol J Environ Stud 24(4): 1477-1490.

2. NKLA Manaf, MA Hassan, NH WAWAK (2015) Biogas Harvesting from Organic Fraction of Municipal Solid Waste as a Renewable Energy Resource in Malaysia: A Review. Pol J Environ Stud 24(4): 1477-1490.

3. K Kawai, T Tasaki (2016) Revisiting estimates of municipal solid waste generation per capita and their reliability. J Mater Cycles Waste Manag 18: $1-13$.

4. TF Khanom, T Farjana, A Al Mamun, A Hossain, AM Baten (2015) Household satisfaction on solid waste collection services conducted by NGOs in Mymensingh Municipality, Bangladesh. International Journal of Natural and Social Sciences p. 14-22.

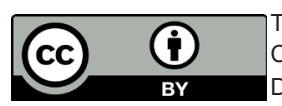

This work is licensed under Creative Commons Attribution 4.0 License DOI: 10.19080/IJESNR.2018.13.555865
5. MA Akaateba, I Yakubu (2013) Households' Satisfaction Towards Solid Waste Collection Services of Zoomlion Ghana LTD Wa, Ghana. European Scientific Journal 9(32): 198-213.

6. AI Anestina, A Adetola, IB Odafe (2014) Performance Assessment of Solid Waste Management following Private Partnership Operations in Lagos State, Nigeria. Journal of Waste Management.

7. T Getahun, E Mengistie, A Haddis, F Wasie, E Alemayehu, et al. (2011) Municipal solid waste generation in growing urban areas in Africa: current practices and relation to socioeconomic factors in Jimma, Ethiopia. Springer Science+Business Media 184(10): 6337-6345.

8. CSA (2008) Summary and Statistical Report of the 2007 Population and Housing Census Population Size by Age and Sex. Central Statistic Agency of Ethiopia, Addis Ababa, Ethiopia.

9. R Joshi, S Ahmed (2016) Status and challenges of municipal solid waste management in India: A Review article. Cogent Environmental Science 2: 1139434

10.MK Tegegn (2008) Household Solid Waste Generation Rate and Physical Composition Analysis, In Jimma Town Ethiopia. Masters Thesis, Addis Ababa University, Addis Ababa, Ethipia.

11.S Barr (2007) Factors Influencing Environmental Attitudes and Behaviors: A U.K. Case Study of Household Waste Management. Environment and Behavior 39(4): 435-473.

12. BK Demanya (2007) The Role of Local Knowledge in planning and managing urban solid waste: the tale of two (2) West African Cities, Accra and Kumasi, Ghana. University of Waterloo Library.

13.E Wokekoro, MP Inyang (2007) Waste disposal in low-income Neighbourhoods and its impact on health: The case of port Harcourt, Nigeria. International Conference "Waste Management, Environmental Geotechnology and Global Sustainable Development (ICWMEGGSD'07 - GzO'07), Ljubljana, Slovenia.

14. KK Ro (2017) Municipal Solid Waste Management in city of Motihari. International Journal of Scientific \& Engineering Research 8(4): 394401.

15. B Maskey, M Singh (2017) Households' Willingness to Pay for Improved Waste Collection Service in Gorkha Municipality of Nepal. Environments 4(4): 77.

16. NA Kumari, hL Pathi, KD Priya, PS Vineel (2016) Solid Waste Management. International Journal of Advanced Research in Science and Engineering 5(4): 359-368.

17. WHO (2015) Waste and human health: Evidence and Needs. WHO Regional Office for Europe, Bonn, Germany.

18.Z Abebe, F Kebede (1999) Assessing awareness and practice of solid waste. Integrated developemnet for water supply and sanitation, Addis Ababa.

\section{Your next submission with Juniper Publishers} will reach you the below assets

- Quality Editorial service

- Swift Peer Review

- Reprints availability

- E-prints Service

- Manuscript Podcast for convenient understanding

- Global attainment for your research

- Manuscript accessibility in different formats

( Pdf, E-pub, Full Text, Audio)

- Unceasing customer service

Track the below URL for one-step submission https://juniperpublishers.com/online-submission.php 